\title{
The Auld Wives' Lifts
}

\section{LESLIE ALCOCK}

\begin{abstract}
This is an account of the severed heads on the Auld Wives' Lifts, Craigmaddie Muir, Scotland, by the Professor of Archaeology, University of Glasgow. The Auld Wives' Lifts is an object of interest and debate for geology, antiquarianism, folklore, vernacular art and, perhaps, Celtic iconography, and we are glad to give it publicity.
\end{abstract}

The Auld Wives' Lifts stands at an altitude of just under $180 \mathrm{~m}$ oD (Nat. Grid Ref. NS 582764 ) on Craigmaddie Muir, some $\mathrm{II} \mathrm{km}$ north of the centre of Glasgow. The Muir, a rolling heathercovered moorland of eponymous sandstone, is an area of some archaeological richness, with two chambered tombs, several cairns, and a group of cup-and-ring markings. The Craigmaddie sandstone was also excellent for millstones, and every stage in their manufacture can be detected on the moor.

The first mention of the Lifts appears to be the description in Ure's History of Rutherglen and East Kilbride (1793, 85-7). Ure gives a wood-cut which shows that the Lifts comprises two large boulders 'of a prismatical shape' which support a third block which 'seems to have been a regular parallelopiped'. Beneath the capstone is a narrow and irregular gap, which does not reach down to ground level, and 'through this opening, so superstition says, every stranger who visits this place for the first time must creep, otherwise he shall die childless'. Ure adds the traditional account of the name, that 'three old women, having laid a wager which of them would carry the greatest burden, brought, in their aprons, the three stones and laid them in position'. To this account we may add the dimensions of the capstone, since this is the most conspicuous feature of the Lifts. In plan it is an irregular diamond, some $6.0 \mathrm{~m}$ long by $4.0 \mathrm{~m}$ broad. Its northeastern corner stands $3.40 \mathrm{~m}$ above the ground, and its southwestern $3.70 \mathrm{~m}$. Its thickness is variable but in general about $2.0 \mathrm{~m}$.

Ure had no doubt that the Auld Wives' Lifts was in reality a Druid altar, one of the few 'yet remaining, after all the dilapidations that ignorance, avarice and superstition have occasioned'. 'The sacred grove', Ure continues, 'hath long ago yielded to the all-subduing hand of time, yet not without leaving behind traces sufficient to convince us of its existence' for 'roots and stumps of oak trees yet remain in their natural position.' The three old wives themselves he regarded as a reminiscence of the Druidesses who had superintended the sacred rites.

The belief that the Lifts was a druidical altar persisted throughout the nineteenth century, often expressed in the very terms used by Ure. One of the most interesting aspects of this is the recurrent mention of the visible stumps of the sacred grove. There are no signs of such stumps today! My colleague $\mathrm{Dr}$ J. H. Dickson informs me that the peat around the Lifts is up to $1.0 \mathrm{~m}$ deep and contains occasional wood, probably birch and willow; none of it is obviously oak. Throughout the century, too, the standard account received various imaginative embellishments. It would be amusing or tedious, according to the reader's taste, to list all the references in local histories and topographies; to the 'gruesome but not altogether disagreeable feeling pervading us as we stand upon the stone of blood' (Macdonald, 1856,366 ); or to the 'vast assemblages of grim and resolute warriors bending reverentially around the central group of their mighty priesthood' (Robertson, 1867, 9). They may be summed up in two sentences. 'Probably no better example exists of the rude stone altar of Druid times. Here .... stands the great pagan cathedral of western Scotland' (Todd, $1898,2-3$ ).

The interpretation of the Lifts as an altar did not go unchallenged, however. Daniel Wilson, father of the term 'prehistoric', described it as 'one of the most celebrated Scottish cromlechs' ( 1863,93 ); 


\section{ANTIQUITY}

and about this time, too, it appeared on a local map as a 'Druidical Cromlech'. There were even sceptics 'who aver that this stupendous monument is more likely to have been the work of nature than of man' (Robertson, 1867,8 ). In 1867 such heretics might, indeed, be condemned for displaying their ignorance of the past, but within a few years, arguments for a natural origin were being put forward in a popular series of geological excursions (Bell, I88I, 66). The debate appeared to have been settled in 1916 by J. W. Gregory's detailed examination of the three stones themselves, and of their bedding planes in relation to those of the surrounding scarps. He claimed that it was possible to correlate depressions and protrusions on the capstone and the two supporters in such a way as to demonstrate that they had originally formed a single block or tor, isolated by the excavating action of ice. This tor was subsequently weathered and split so that the lower part, now in two, slipped and tilted, while the upper layer settled into the hollow thus formed. The Lifts, then, he 'regarded as a pseudo-megalithic tor' (Gregory, 1916, 282).

Accepting a natural origin, it was nonetheless recognized that the Lifts had one feature which could only be attributed to man. Robertson appears to have been the first to notice, incised on the level top of the capstone, a circle $90 \mathrm{~cm}$ in diameter. 'Notwithstanding the hundreds that visit this curious relic every year, and for as often as it has been described by archaeologists, this is the first time that this typical figure has ever been brought under notice, no one previously having observed it, or, if so, without attaching any importance to it' (Robertson, 1867,5 ). He admits that 'the greater part of the upper surface where this symbol occurs is much disfigured by roughly cut initial letters, and names of thoughtless visitors, rendering it less observable than it would otherwise be.' This circle was surveyed by F. R. Coles early in the present century (1905-6, 298).

Robertson considered the circle to be an 'ancient sanctifying emblem', and further proof, therefore, of the druidical function of the Lifts. Coles permitted himself to 'smile at the notion of such masses of stone having any connection with Druidical rites' (1905-6, 300), but offered no explanation for a very deliberate piece of workmanship. It was left to the Stirlingshire Inventory, in 1963 , to suggest that the circle 'may well have been made by a quarryman engaged on cutting out millstones near by' (Inventory, 446). This is indeed highly likely, for the greater part of the surface of the capstone has been lowered about $20 \mathrm{~cm}$, leaving projecting lips on the east and west sides. It is probable that this was done in winning quern-stones, and the circle may be either the last trace of a quern already removed, or the marking out for a quern-stone which had never in fact been cut.

Meanwhile, an explanation of the origin of the Lifts had been proposed that differed from Gregory's, namely that 'the general opinion at the present day is that the rocks were transported and deposited by ice' (Bassett, 1958, 35). It is evident that there were two principal weaknesses in Gregory's interpretation. First, the supposed correspondences in the irregularities of the surface of the stones are unconvincing, especially so when Gregory claims that 'the opposite faces of the two supporting stones are counterparts', for the north face of the southern supporter is almost totally buried. Secondly, his explanation of the formation of a tor in a glacial region is now thought unlikely. Bassett's alternative hypothesis is certainly more attractive. Blocks very similar in shape and size to the two supporters can be seen in the vicinity of many of the short natural scarps which abound on the moor.

Recent discussion with geological colleagues suggests, however, that the natural status of the capstone may be more questionable. There are in fact very few large transported blocks to be seen on the moor. That one of the few should happen to have been deposited on a pair of supporters may be a remarkable coincidence; that it should have been set virtually level, its irregular underside fitting the irregularities of the supporters, and its long axis matching the gap between them, may be stretching coincidence to unacceptable lengths. The alternative suggestion, that the capstone at least may have been humanly placed, appears no less difficult. The weight, between 60 and 70 tonnes, may be no real obstacle, expecially as the lift required is only about $1.5 \mathrm{~m}$. The problem would be to find other examples of capstones raised on supporters, whether natural or artificial, which had no chamber or gap at ground level.

Further extensive research, both geological and archaeological, would be needed to provide a satisfactory explanation of the origin of the Lifts. Such research lies outside the scope of this article. The present purpose is to report that, in addition 


\section{THE AULD WIVES' LIFTS}

to names, initials and dates, and the circle on the capstone, the Lifts also bears a number of carved and incised heads. These are not mentioned in the literature, and appear first to have been noticed early in 1975 . Since a case can be made that these carvings are not recent, they are reported in detail to forehead, $165 \mathrm{~mm}$; overall, chin to tip of horn, $260 \mathrm{~mm}$.

Head $B$ (PL. XVII $b$ ). At the bottom edge of the east face of the capstone, a head and neck in shallow relief. The head probably exploits a low natural boss which has been accentuated by a wide $\mathrm{V}$

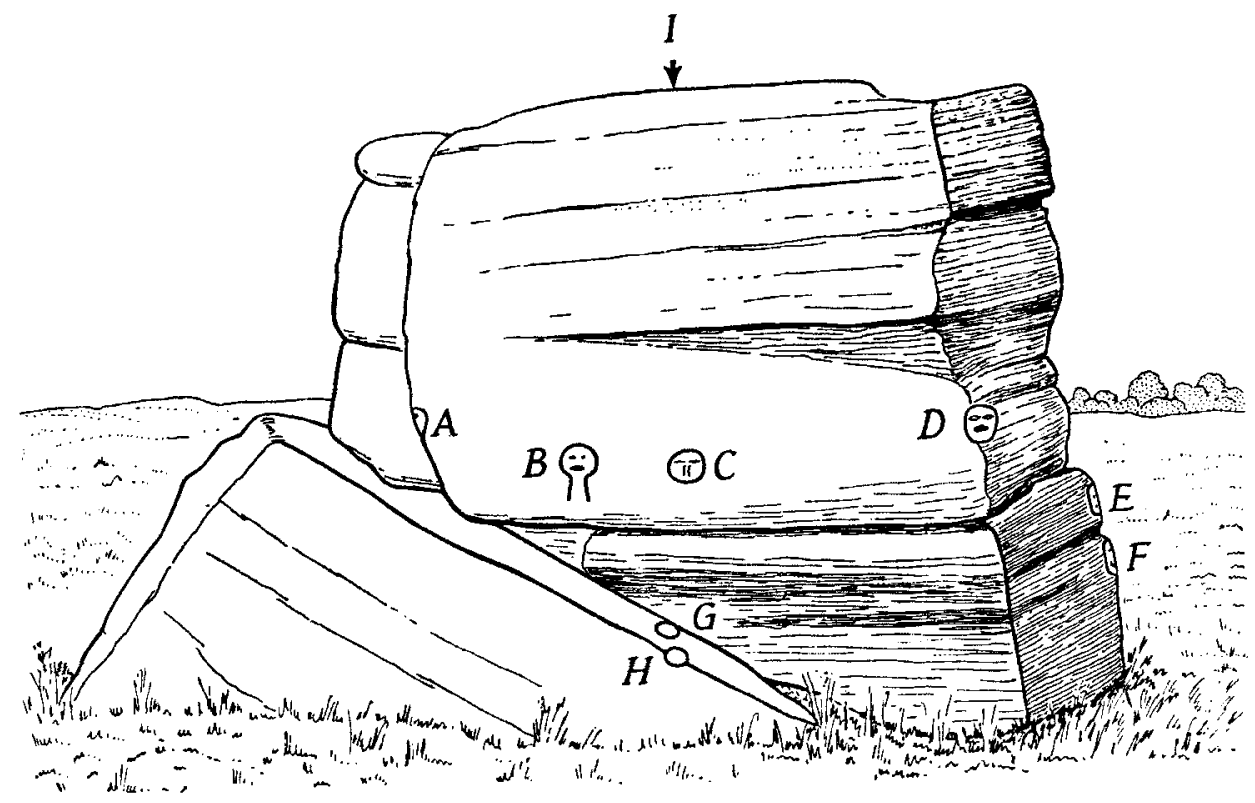

Fig. I. Sketch of the Auld Wives' Lifts from the east, showing the location of the individual heads

here (FIG. I; PL. XVI). The account is a synoptic one, based on numerous visits, in varied conditions of weather, light and lichen growth. Not all the features described here are necessarily visible on any one occasion, and some details no doubt have still to be recognized.

Head $A$ (PL. Xvila). On the eastern edge of the south face of the capstone is a horned or crowned head in low relief, probably carved from a natural boss. Incised lentoid eyes under beetling brows, with a suggestion of eye-lid in the left eye; crudely incised mouth $17 \mathrm{~mm}$ deep; nose probably originally in relief, but now badly damaged. On the right, a leaf-shaped 'horn' rises above a horizontal line marking the forehead; the outer side of the horn is very clearly defined, and was probably based on a natural fissure in the rock. A clear scar shows where a similar horn has flaked away from above the left temple. An appearance of hair on the right side is probably merely the result of lowering the field to increase the impression of relief. The whole head tilts very slightly to the viewer's left. Height, chin groove; the neck has been produced by lowering the field, and then giving sharper definition with a narrow groove. The mouth is almost certainly a naturally-formed funnel-shaped pocket, $65 \mathrm{~mm}$ wide by $45 \mathrm{~mm}$ high by $50 \mathrm{~mm}$ deep, which has been deepened a further $20 \mathrm{~mm}$ by a cylindrical drill hole $10 \mathrm{~mm}$ in diameter. The eyes are likewise drill holes $10 \mathrm{~mm}$ in diameter and up to $6 \mathrm{~mm}$ deep. There are faintly incised eyebrows. The nasal area and part of the brow have been heavily battered recently, showing white scars which reveal the unweathered colour of the rock. Height $300 \mathrm{~mm}$.

Head C (PL. xvina). Incised circular head, at the bottom edge of the east face of the capstone. Outlined by a continuous groove; no true relief, but a slight lowering of the field above the left temple. Incised eyes and mouth; nose delineated by two parallel lines. Diameter $175 \mathrm{~mm}$.

Head $D$ (PL. xVIII $b$ ). On the north-east arris of the capstone, at the same general level as Head A, an elaborately carved head in relief. The relief has been achieved partly by exploiting the arris of the 


\section{ANTIQUITY}

rock, partly by lowering the field. The nose and chin have been heavily damaged, sufficiently long ago for the scars to have weathered to the same colour as the rest of that area of the capstone. The gaping mouth may also have been partly distorted by damage, and the left eye is also partly damaged. The quality of the original carving may be judged from the right eye, which has a roughly diamondshaped double outline and a central perforation. Down the right side is a long scar, partly ancient and heavily weathered, partly less weathered, which starts above the forehead and continues well below the chin. It is not clear whether this is merely a lowering of the field to increase the relief or whether it is the final trace of very full and flowing hair. The left side is altogether too damaged to provide evidence on this point. Height about $180 \mathrm{~mm}$, but difficult to measure because of damage.

Head $E$. On the north arris or angle of the northern supporting stone is a crude head which exploits the arris to create a semblance of relief. Although there is no doubt about the outline, the face itself is so crudely executed and battered that no two observers can agree about the identification of eyes, nose and mouth. The outline seems to have been produced by a series of separate chisel cuts, with no attempt to inscribe a continuous line. Height $200 \mathrm{~mm}$.

Head $F$. Immediately below Head $\mathrm{E}$ is a second incised head, slightly less crude. Continuous outline; deep lentoid eyes, the right eyebrow clear, the left less so; the bridge of the nose clearly defined between the eyes but the nose itself is missing; the mouth also appears damaged but may have been a simple incised line.

Head $G$. A circular incised head on the inner slope of the southern supporter, badly worn, perhaps by people clambering through the gap under the capstone. The circular outline and the right eye are clear, and so are two parallel lines for the nose. There is a faint hint of the left eye; a straight stroke above it may be either an eyebrow, or more probably an unfinished initial. The mouth and lower part of the face, if they were ever present, have been totally lost through wear. Diameter I Io $\mathrm{mm}$.

Head $H$. On the outer eastern edge of the southern supporter is a head in false relief, outlined by a wide groove. Incised lentoid eyes beneath well-marked brows in relief. The bridge of the nose is clear, but the lower nose and mouth are damaged. Height I $55 \mathrm{~mm}$.

Head I. On top of the capstone, just west of the inscribed circle, a profile bust, in simple outline, with a drilled eye. An effect of false relief is produced by easing the slope from the centre of the head into the outline groove and then out again into the field. The hooked nose and chin give a ' $\mathrm{Mr}$ Punch' look to this bust, which is totally different in conception from the other eight heads.

So much for the geology, history and description of the Auld Wives' Lifts and its carved heads. What remains are discussion, speculation and hypothesis. The first question must be why it is only now, two hundred years after the first record of the Lifts, that the heads are being reported. This is obviously relevant to any discussion of the possible age of the carvings.

Indeed, it may be argued that the silence of a long line of competent observers shows that the carvings are later than any available account of the Lifts. Robertson's description is relevant here, because he notices and complains about the disfiguring names and initials, so if the carvings had been visible in his day, it seems reasonable to expect that he would have mentioned them. Even more telling for this argument is Coles's silence in r905, for in the course of surveying the three stones and the incised circle he must surely have noticed the other carvings had they been present.

Unhappily for this convincing logic, there is evidence that Heads $A, B, C$, and $D$ had been carved before I905. Head A can be detected on a photograph taken by the well-known Glasgow artist, $\mathrm{Wm}$. Young, in 1887 , and now preserved in the Mitchell Library (accession 466849: Photographic Scraps, Vol. 2, p. 55). Heads B, C and D can likewise be discerned on a photograph taken at about the same date, by John Cameron, Kirkintilloch, and now preserved in an album in the possession of $\mathrm{Mr} \mathrm{L}$. V. Cameron of Lenzie. In neither case does it appear that the photographer was aware of what his own picture showed.

If this should seem strange, then the belated recognition of the axe-carvings at Stonehenge may appositely be recalled (Atkinson, 1952). Moreover, it should be stressed that under many conditions of weather and lighting, the Craigmaddie carvings are not at all clear. In PLS. XVII and XVIII, the clearest of them are illustrated by photographs taken under ideal lighting, in the course of numerous visits to the Lifts. But several students of archaeology, some of them acute observers, have failed to notice the faces even after they had been repeatedly told that they were missing important features of the site. Finally, one may recall Robertson's words about his discovery of the circle on the capstone 'no one previously having observed 


\section{THE AULD WIVES' LIFTS}

it, or if so, without attaching any importance to it'.

At this point the objection might be raised that if the carvings had been in existence in the last century, and if they had been recognized, then importance would certainly have been attached to them as evidence in favour of the interpretation of the Lifts as a druidical altar. But this is not necessarily so. Piggott's account of what he calls 'the Romantic image' of Druidism (1975, Ch. Iv), would suggest that Druidism was thought of as an essentially aniconic religion: using stone circles and sacred groves, no doubt, and altars for bloody sacrifices too, but not representing its deities under human visage. It is worth recalling that despite Caesar's reference to the plurima simulacra of the Celtic god whom he identified with Mercury, Kendrick could still believe 'that large body of conservative druidism ... . was definitely hostile to anthropomorphism' (Kendrick, $1927,145)$. It is likely, therefore, that even if Robertson had noticed the carvings, he would not have considered them as evidence for a druidical altar.

Since the argument from the silence of recent observers clearly fails, we must turn to other criteria in attempting to assess the age of the heads. First, the superficial appearance of the carvings may be compared on the one hand with very recent dated inscriptions, and on the other with nineteenth-century incriptions, which go back at least to $\mathrm{r} 807$. While the modern names and initials are white and raw, earlier ones have mellowed to a dark grey or black; and so have all the heads. Moreover, in the case of Heads $\mathrm{A}$ and $D$, the scars of damage which must be subsequent to the original carving are likewise dark and weathered: the scar which removed the left horn of Head $A$, and the scars on the forehead, nose and chin of Head D. This last head has, indeed, every look of battered and venerable antiquity. Nor can it be argued convincingly that the rock, being sandstone, would necessarily weather rapidly. At the millstone quarry on the scarp of Craigmaddie Muir, individual tool marks, including finelypecked marking-out rings, are still clear-cut after, perhaps, two hundred years of weathering. Likewise on the scarp above North Blochairn farm are cup-and-ring carvings with the land between the cup and the ring still standing up to $5 \mathrm{~mm}$ above the grooves.

Few chronological clues are provided by the style of the carvings. On any reckoning, they are examples of vernacular or folk art, to which rigorous stylistic criteria can scarcely be applied. For this reason, no attempt is made here to give a comprehensive list of parallels. A few hints must suffice, based on a cursory survey of examples published, for the most part, in standard works on art history. They must be considered in the light of the recent discussion of the Roman or medieval head, altogether more accomplished in both conception and execution, from the Bon Marché site, Gloucester (Greene, 1975). It may at least be hoped that the publication of the heads will stimulate scholars with a more detailed knowledge of insular sculpture to confirm or refute the suggestions made here.

The clearest stylistic element is represented by the eyes of Head D, with their double outline and central hollow. Parallels for this may be readily adduced from Roman Britain. Near at hand, among sculptures from the Antonine Wall, there is a particularly good parallel in the nymph from Duntocher (Macdonald, I934, P1. lxxvii, 5). To this may be added the Victory on the distance slab from Old Kilpatrick (Macdonald, 1934, Pl. lxix, 2), and several figures, both human and divine, on the recently-discovered slab from Hutcheson Hill (Robertson, I970).

Ranging more widely, the supposed head of an underworld goddess from Towcester, Northants (Toynbee, 1962, Pl. 52); a funerary Attis from Caerleon, Gwent (Boon, 1974-6, Pl. ivb) and the head of Antenociticus from Benwell, Northumberland (Toynbee, 1964 , Pl. xxviiia), may all be cited. These examples are of distinctly romanized works, but inevitably the same stylistic device was taken over into works whose inspiration appears to be Celtic rather than Roman. In particular there are several tricephalic heads, for instance, from Bradenstoke, Wilts. (Ross, $1967 \mathrm{~b}, \mathrm{Pl}$. iv) and from Greetland, Yorks. (Jackson, 1968, backpiece).

A similar treatment of the eyes was popular in Romanesque sculpture, especially for mask-faces with deep-drilled pupils (Henry and Zarnecki, I957-8, e.g. Pl. x; Lockett, I97I, Pl. xiv). But it was also used in a more naturalistic way in biblical scenes: the miraculous draught on a capital at Lewes Priory (Boase, 1953, P1. I 5a); the judgement of Solomon on a capital at Westminster Abbey (Boase, I953, Pl. I6) and various scenes from the west front of Lincoln Cathedral (Gardner, I95I, Pl. 154), to name a few specific examples. Comparable eyes in Gothic sculpture are rather 


\section{ANTIQUITY}

rare, partly because figures are so frequently represented in death; but they enjoy a vigorous revival in Renaissance and later sculpture in the Classical mode. Near at hand are the splendid figures which adorn the outer walls of the midsixteenth-century palace at Stirling Castle; or, in wood, the famous oak medallions known as the Stirling Heads (Stirling Inventory, Pls. 76, 77, 86). Indeed, it could well be argued that Head D is but a yokel's version of these accomplished works.

A second group of rather generalized parallels is provided by circular, moon-like faces in low relief or incised outline. These are represented by Heads $\mathrm{C}, \mathrm{G}$ and $\mathrm{H}$, and possibly Head $\mathrm{B}$ as well. Romano-Celtic analogies may be cited from Coventina's Well, Carrawburgh, Northumberland (Ross, I967a, Pl. 9b); Wallsend, also in Northumberland (Ross, 1967a, Pl. 33b) and Charterhouse on Mendip, Somerset (Ross, 1967a, Pl. 33c). But again the type, if such it may be called, is long-lived, and in vernacular art it is well represented by angels on headstones. Examples from the eighteenth century are well illustrated, for instance, in Burgess (1963, Pls. I (1718, 1722); 4 (1723); 26 (1737, 1741); $29(1728)$ ). Head C (and possibly G), however, have one feature which, simple though it seems, is not often found: the nose represented by two parallel incised lines. For this we may compare a warrior or war god from the Roman auxiliary fort at Maryport, Cumberland (Ross, 1967a, Fig. 128 and Pl. 63c).

From this inconclusive discussion of style we may turn to consider whether there is any detectable iconography in these heads. Excluding the profile bust I and, for the moment, Head B, there is on the Auld Wives' Lifts a group of no less than seven full-face bodiless heads. As a group, they recall irresistibly the severed heads of Gaul, one of the leading images of Celtic religion (Lambrechts, 1954; Ross, r957-8). Even Head B, with its well-defined neck, is not totally alien to this category: compare, for instance, sculpture in relief from Vienne and Argentan (Lambrechts, 1954, Figs. 45, 49). Severed heads occur on funerary monuments, on stelae or standing stones, and on architectural lintels, though admittedly they do not seem to occur on living rock or natural features. But how would a Celtic sculptor -if for the sake of discussion we may allow suchhave regarded the Auld Wives' Lifts? If Daniel Wilson thought that it was a cromlech, then the possibility cannot be dismissed that in earlier times too it had been regarded as a monumental tomb. The Celtic and Roman interest in, and use of, various classes of megalith have recently been affirmed by Daniel (1972). And even if the specific idea that the Lifts was thought of as a tomb is rejected, it might still have been regarded as a marvel, an object of wonder and veneration.

Apart from the generalized idea of severed heads, two more specific analogies in Celtic iconography may be noticed. The first is the mouth of Head B. This was initially a natural pocket, and there is little doubt it was this which occasioned the precise location of the head. But the natural hollow has been deepened by drilling, using the same technique as that for the eyes. This recalls the small holes, closely comparable in size to the drilled deepening of the mouth of Head $B$, which occur either centrally or to one side of the mouths of the tricephalic heads from Greetland, Yorks (Jackson, 1968) or the head now at Hendy, Llanfair Pwllgwyngyll, Anglesey (Lynch, 1970, Fig. 92).

The other very specific Celtic parallel is provided by Head $A$. It is clear that this originally had some form of head-dress, horns, or crown, and the scarring of the rock shows that much of this has been lost. It may reasonably be restored on a basis of symmetry. Crowned heads are, of course, a commonplace of medieval figure sculpture, but it really is impossible to postulate any form of medieval crown here. The simplest solution is to restore a single horn on the left of the head, comparable with that on the right. If this is accepted, it is very difficult to resist the idea that this is a representation of Cernunnos, the horned god of the Celts (Ross, 1967a, Ch. III).

Against these claims to find plausible parallels in style and iconography in the religious imagery of the Celts, a healthy scepticism will urge that these heads are nothing more than the work of visitors in recent times, the product of the same idle hours as the names and dates. But the sceptic must explain one quite objective difference between the heads and the graffiti. Names and initials are scattered at random on all sides of the Lifts, and on all accessible surfaces: the heads occur only on the east and north. This is not because of ease of access, for while Heads E, F, G and $\mathrm{H}$ are easily accessible, A, B, C and D all involve a long stretch, or even the piling up of a small platform of boulders. Moreover, the two prime positions on the capstone are its south-east and north-east 


\section{'THE AULD WIVES' LIFTS}

arrises. These are occupied by the two bestcarved heads, A and D. This seems a remarkable coincidence if the carvings are merely the work of casual visitors.

Whatever is thought of these arguments, one conclusion seems inescapable: that the faces on the Lifts deserve more of archaeologists than to be overlooked or dismissed out of hand. They are at least interesting examples of vernacular art. And beyond this, Head A has a haunting look which is not without its aesthetic appeal, appropriate to the lonely moorland setting; while the surviving eye of Head D shows that in its pristine state this was a distinguished piece of rural craftsmanship.

Acknowledgements: I am most grateful to MrF.L. Sandman for allowing me ready access to Craigmaddie Muir; to E. A., P. A. and J. R. Alcock for their part in the original discovery and subsequent recording of the heads; to numerous colleagues for criticism and advice, especially J. C. Barrett, P. Crew, J. H. Dickson, W. G. Jardine, R. J. Price and W. D. I. Rolfe; and to M. S. Moss and M. Primrose for discovering the 1880 s photographs.

\section{BIBLIOGRAPHY}

ATkinson, R. J. C. 1952. The date of Stonehenge, Proc. Prehist. Soc., XvIII, 236-7.

BASSETT, D. A. 1958. Geological excursion guide to the Glasgow district (Kendal).

BELL, D. I881. Among the rocks around Glasgow (Glasgow).

BOASE, T. S. R. 1953. English art IIOO-I2 I6 (Oxford).

BOON, G. C. 1974-6. Three Caerleon sculptures, Bull. Board Celtic Stud., Xxvi, 227-30.

BURGESS, F. 1963. English churchyard memorials (London). Coles, F. R. 1905-6. Notices of standing stones, cists, and hitherto unrecorded cup-and-ring-marks in various localities, Proc. Soc. Antiq. Scotland, xL, 291-327.

DANIEL, G. B. 1972. Megaliths in history (London).

GARDNER, A. I951. English medieval sculpture (Cambridge).

GReEne, K. T. 1975. The Romano-Celtic head from the Bon Marché site, Gloucester: a reappraisal, Antiq. Fourn., LV, 338-45.

GREgORY, J. W. I9I6. 'The Auld Wives' Lifts-a pseudomegalithic tor, Scottish Geog. Mag., xxxIr, 279-82.

HENRY, F. and G. ZARNECK1. 1957-8. Romanesque arches decorated with human and animal heads, Fourn. Brit. Archaeol. Assoc., 3rd series, xx-xxI, I-34.

JACKson, s. 1968. Tricephalic heads from Greetland, Yorks., Antiquity, XLIl, 314-5.

KENDRICK, T. D. 1927. The Druids, a study in Keltic prehistory (London).

LAMBrEchTS, P. 1954. L'exaltation de la tête dans la pensée et dans l'art des celtes (Bruges).
LOCKETT, R. B. I97I. A catalogue of Romanesque sculpture from the Cluniac houses in England, Fourn. Brit. Archaeol. Assoc., XxxIv, 43-61.

LYNCH, F. 1970. Prehistoric Anglesey, the archaeology of the island to the Roman Conquest (Llangefni).

MACDONALD, G. I934. The Roman wall in Scotland (Oxford).

MACDONALD, H. 1856 . Rambles round Glasgow, 2nd edition (Glasgow).

PIgGoTt, s. 1975. The Druids, and edn. (London).

ROBERTSON, A. D. 1867. Druidical altar, Craigmaddie, Parish of Baldernock, Stirlingshire, Trans. Glasgow Archaeol. Soc. (published i 883), 4-ro.

ROBERTSON, A. s. I970. Roman finds from non-Roman sites in Scotland, Britannia, 1, 198-213.

Ross, A. 1957-8. The human head in insular pagan Celtic religion, Proc. Soc. Antiq. Scotland, xc1, 10-43.

r967a. Pagan Celtic Britain, studies in iconography and tradition (London).

1967b. A Celtic three-faced head from Wiltshire, Antiquity, XLI, 53-5.

STIRLINGSHIRE INVENTORY. I963. Royal Commission on Ancient and Historical Monuments of Scotland, Stirlingshire, an inventory of the ancient monuments.

TODD, G. E. (ed.). 1898. The book of Glasgow cathedral (Glasgow).

TOYNBEE, J. M. C. 1962. Art in Roman Britain (London). 1964. Art in Britain under the Romans (Oxford).

URE, D. 1793. The history of Rutherglen and East Kilbride (Glasgow).

WILSON, D. 1863. Prehistoric annals of Scotland, and edn. (London).
In the way of college-courts and quiet scholastic porticoes, of gray-walled gardens and ivied nooks of study, in all the pictorial accidents of a great English university, Cambridge is delightfully and inexhaustibly rich.

HENRY JAMES

\section{All this and}

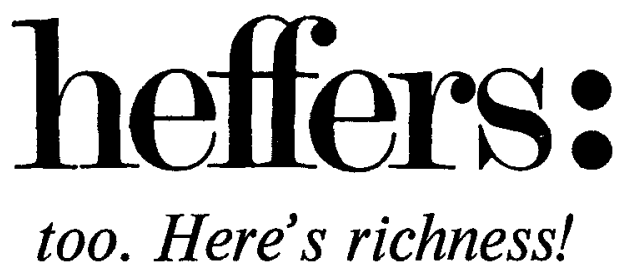

Heffers Bookshop, 20 Trinity Street, Cambridge 


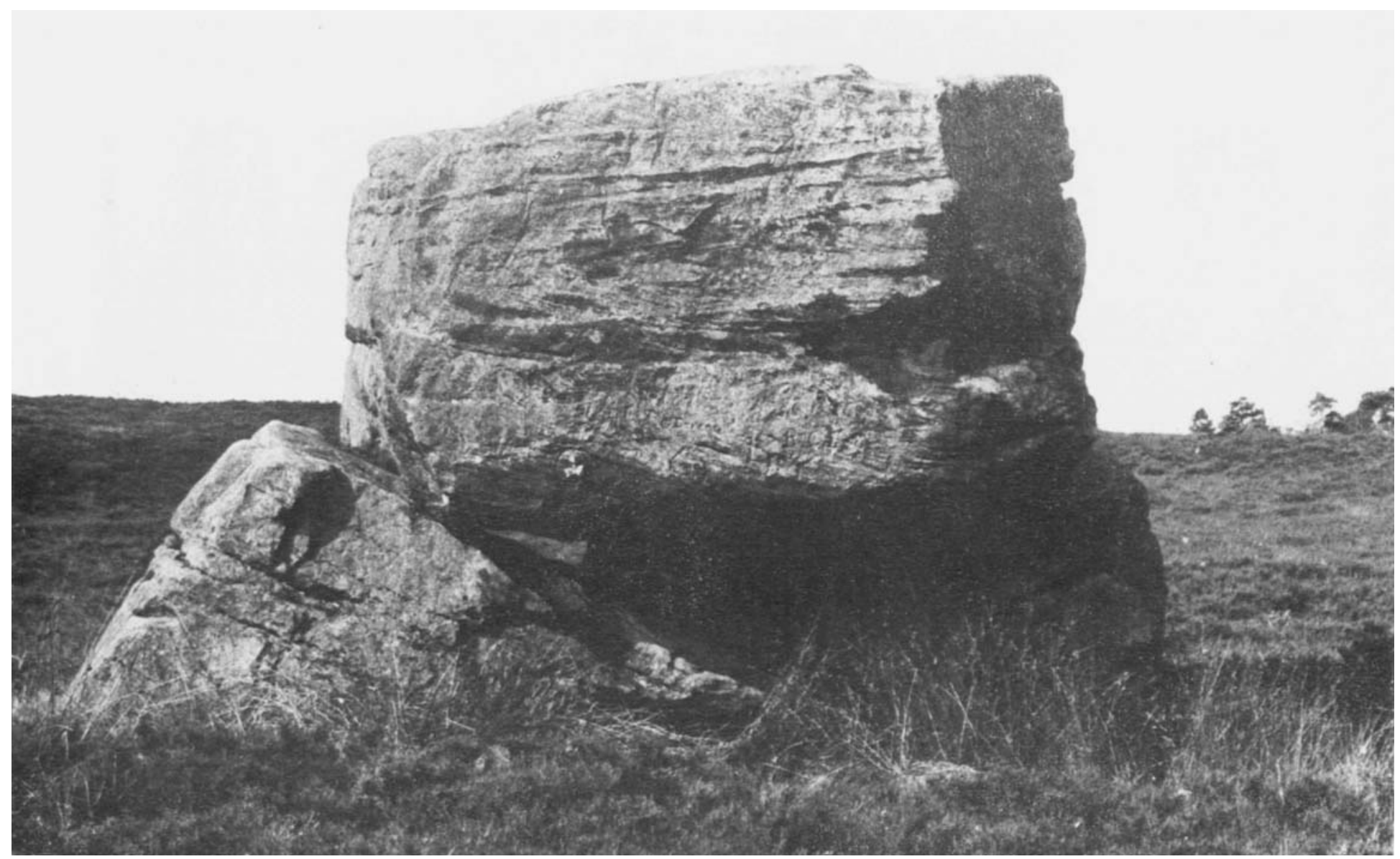

PLATE XVI: THE AULD WIVES' LIFTS: general view from the east 

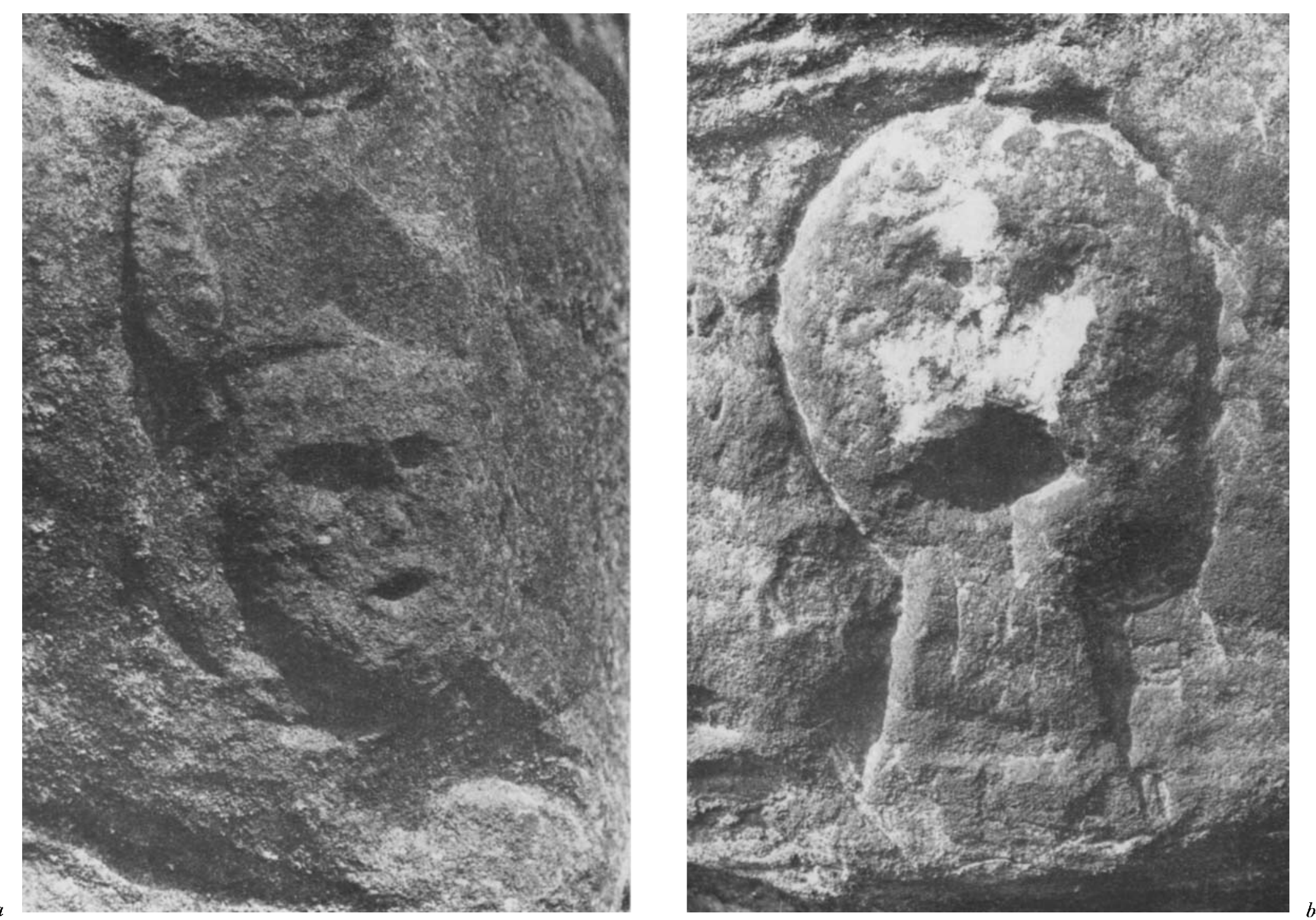

Plate xVil: the Auld wives' lifts: (a) Head $A$; (b) Head $B$ 

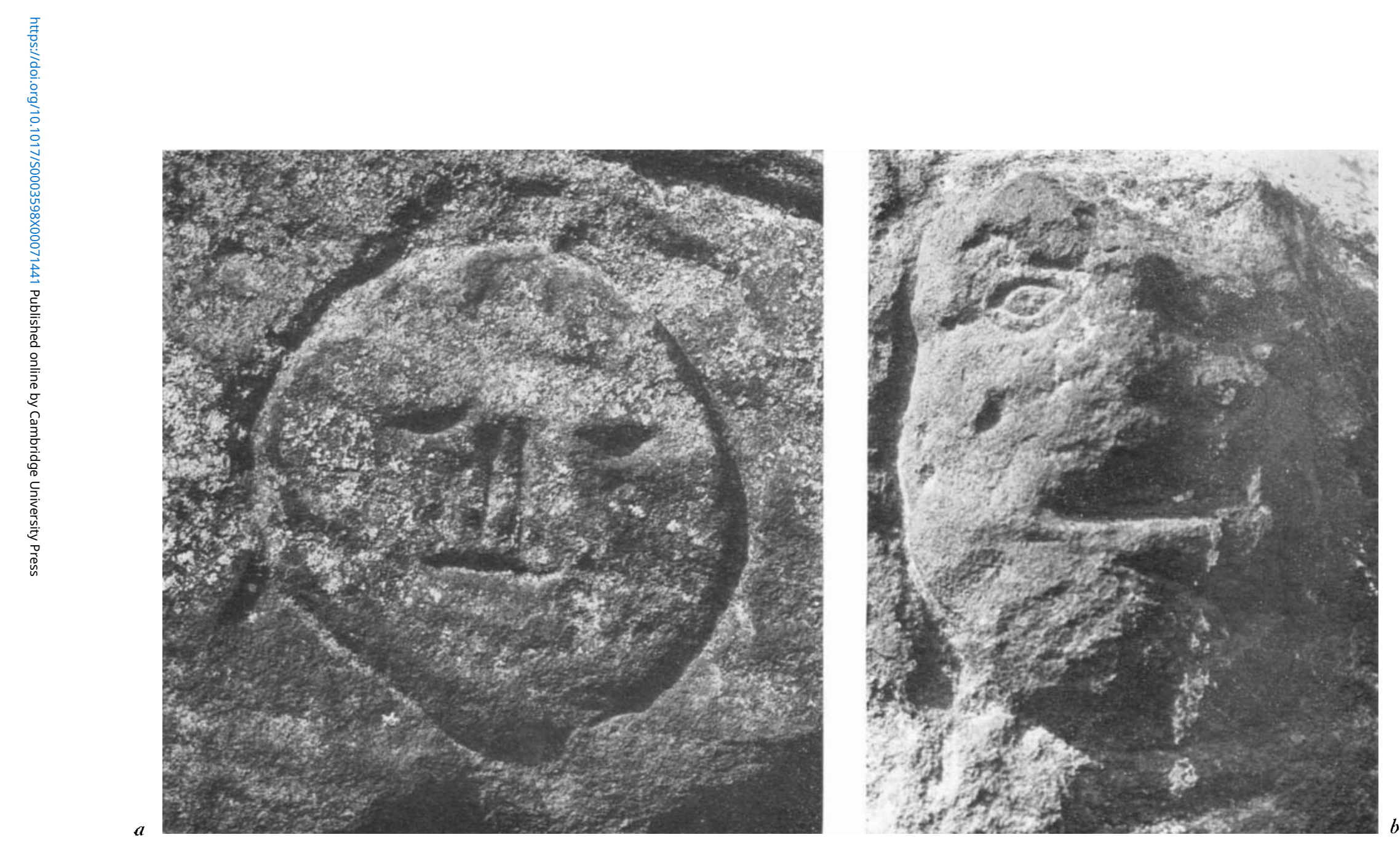

PLATE XVIII: THE AULD WIVES' LiFTS

(a) Head C; (b) Head D 